\title{
Saliva Based Oral Cancer Diagnosis - A Review
}

\section{Sarojini K' ${ }^{1}$, Brundha $\mathrm{MP}^{2}$, Smiline Girija $\mathrm{AS}^{3}$}

\section{IJCRR}

Section: Healthcare

Sci. Journal Impact

Factor: 6.1 (2018)

ICV: 90.90 (2018)

(c) (7) (3)

Copyright@IJCRR
Saveetha Dental College and Hospitals, Saveetha Institute of Medical and Technical Sciences, Saveetha University, Chennai- 77 , India; ${ }^{2}$ Associate Professor, Department of Pathology, Saveetha Dental College and Hospitals, Saveetha Institute of Medical and Technical Sciences, Saveetha University, Chennai - 77, India; ${ }^{3}$ Associate Professor, Department of Microbiology, Saveetha Dental College and Hospitals, Saveetha Institute of Medical and Technical Sciences, Saveetha University, Chennai - 77, India.

\section{ABSTRACT}

Oral cancer refers to any malignancy that develops around any part of the mouth like lips, pharynx. Oral squamous cell carcinoma is reported as the top three common malignancies in India. Despite the recent advances, oral cancer has been reported with higher mortality rates all over the world. Saliva has been identified to be an efficient tool in the early detection of oral malignancy and reduces the higher rate of mortality due to late diagnosis. The goal of this saliva-based diagnosis method is to detect malignancy at an early phase and which is a hallmark of salivaomics. The current review focuses on saliva-based oral cancer diagnosis. A review of the literature of research papers on saliva-based oral cancer diagnosis was done from articles duration between 2000 to 2020. Data collection was done through search engines and databases. Articles that met the inclusion criteria have been included. Saliva is a complex fluid containing several hormones, proteins, enzymes, cytokines, antibodies, salts, antimicrobial constituents, and is associated with a variety of systemic diseases. Saliva based diagnosis has been used in the diagnosis of systemic diseases and drug monitoring. Salivary biomarkers have been identified over the years specifically for early cancer detection which has attracted much research interest, especially for oral cancers. Extensive clinical applications of fluids in the human body have been found to diagnose and monitor human health. Detection of molecular markers like DNA, RNA, protein markers in saliva can be accurate and reliable methods for the diagnosis of oral cancer.

Key Words: Biomarkers, Diagnostic tool, Oral cancer, Saliva, Salivary proteins, Salivaomics

\section{INTRODUCTION}

Oral cancer refers to all malignancies arising from the lips, oral cavity, and pharynx. Mostly $90 \%$ of all oral cancers being oral squamous cell carcinoma. ${ }^{1}$ Oral squamous cell carcinoma is reported as the top three commonest cancer in India which affects more than 1 million people per year. ${ }^{2}$ Despite recent advances and technology, oral cancer has been reported as cancer with a higher mortality rate by the world health organization. ${ }^{3}$ The higher death rates in oral cancer are attributed due to the late diagnosis of the disease. ${ }^{4}$ The early identification of oral malignancy is regularly a difficult task and infers more clinical and laboratory examinations that can postpone the treatment and profoundly impact the visualization. ${ }^{5} \mathrm{~A}$ variety of fluids are seen in the human body with a high quantity of proteins such as blood, urine, and saliva, they assess to identify several systemic and oral diseases. ${ }^{6}$ The most important and relevant composition in the saliva is salivary proteins. ${ }^{7}$ Specific proteomic content present in the saliva helps in identifying biomarkers associated with several diseases. ${ }^{8}$ The composition of the saliva varies and depends on the type of gland secretion whether mucous or serous. ${ }^{9}$

Salivary biomarkers have been identified over the years specifically for early cancer detection which has attracted much research interest, especially for oral cancers. ${ }^{10}$ These fluids proved to have found widespread clinical applications to diagnose and monitor human health. ${ }^{11}$ Saliva has been tested as a valuable tool for drug monitoring and diagnosis of the disease. Saliva is a complex fluid containing several hormones, proteins, enzymes, cytokines, antibodies, salts, antimicrobials ${ }^{12}$ constituents, and is associated with a variety of systemic diseases. ${ }^{13}$ Saliva is a more specific and potentially sensitive screening tool, whereas more than 100 salivary biomarkers (DNA, RNA, mRNA, protein markers) have already been identified, including cytokines (IL-8, IL-1b, TNF- $\alpha$ ), defensin-1, P53, Cyfra 21-1, tissue polypeptide specific anti-

\section{Corresponding Author:}

Dr. Brundha M P, Associate Professor, Department of Pathology, Saveetha Dental College and Hospitals, Saveetha Institute of Medical and Technical Sciences, Saveetha University, Chennai - 77, India; Phone: 9884421482; Email: brundha.sdc@saveetha.com

ISSN: 2231-2196 (Print)

Received: 14.09 .2020
ISSN: 0975-5241 (Online)

Revised: 15.10 .2020
Accepted: 12.11 .2020
Published: 26.12 .2020 
gen, dual-specificity phosphatase, spermidine/spermineN1acetyltransferase, profilin, cofilin-1, transferrin, and so on. ${ }^{14}$ Detection of new molecular markers in saliva like DNA, RNA, protein markers in saliva can be accurate and reliable method(s) for the diagnosis of oral cancer. ${ }^{15}$

Moreover, saliva is a diagnostic fluid which can be inexpensive and accounts for early detection of diseases. ${ }^{16}$ The goal of this saliva-based diagnosis method is to detect malignancy at an early stage, and early cancer detection is the hallmark of successful treatment. A salivary diagnostics method should have general functionality, high sensitivity and specificity, low cost, and efficient clinical application. Saliva based detections are non-invasive and accessible diagnostic methodology. With this background, this review summarizes the saliva-based oral cancer diagnosis.

\section{MATERIALS AND METHODS}

A scoping review was made by articles from various search engines including Pubmed, Google Scholar, Cochrane, MeSH core. Related articles from 2000 to 2020 to date have been selected. Articles related to oral cancer, salivanomics, salivary Biomarkers, diagnosis methods were included. Articles related to other cancers and other diagnostic methods of oral cancer have been excluded.

\section{SALIVA: A PERFECT DIAGNOSTIC MEDIUM}

Saliva has been long proposed and used as a diagnostic medium for several systemic diseases. ${ }^{17}$ Because it is a noninvasive, better alternative to serum testing, effective, easily accessible, less time consuming, inexpensive and it can be used for screening large population samples. ${ }^{18}$ Several previous studies have found that salivary levels of specific proteins are increased in the whole saliva of patients with OSCC. CD44 (a cell surface glycoprotein involved in cell-to-cell interaction), 44 Cyfra 21-1 (a fragment of cytokeratin 19), tissue polypeptide antigen (TPS), and Cancer antigen 125 (CA-125) are some examples which have been suggested as oral cancer biomarkers. ${ }^{19}$

\section{SALIVA AND ITS SAMPLE COLLECTION}

Oral samples are useful for the diagnosis of systemic and oral diseases including saliva, gingival crevicular fluid, dental plaques, and oral swabs. ${ }^{20}$ Incorporation of saliva as a diagnostic tool has likely a future perspective. ${ }^{21}$ Several authors have reported significant correlations between the substances present in the saliva and blood. ${ }^{22}$ Saliva can be collected through different techniques. Saliva can be collected in four distinct forms a) collection of resting or unstimulated saliva, b) collection of stimulated saliva, c) collection of glandular saliva (parotid secretions mainly) with or without any stimulation, d) collection of palatine saliva. ${ }^{23}$ Stimulated saliva contains a diluted concentration of biomarkers and it is laborious to collect therefore it is not preferred. Unstimulated saliva is preferred for sample collection rather than stimulated saliva. There are various methods developed for the collection of saliva for samples. ${ }^{24}$

\section{Draining method:}

The individual is made to sit calmly with the head bent down and the mouth open. Saliva drips passively from the lower lip into the sterile tube thereby it is collected. This method has been recognized to be the most reliable as it allows for the collection of unstimulated saliva.

\section{Spitting method:}

Saliva can accumulate in the floor of the oral cavity and the individual spits out it into graduated sterile tubes.

\section{Suction method:}

Collection of saliva made through saliva ejector with the help of micropipettes, syringes, or aspirator. Saliva can accumulate in the floor of the mouth, and it is collected via saliva ejector.

\section{Swabbing method:}

The collection takes place with the help of a synthetic gauge sponge, preweighed swab or cotton pad. The individual is asked to chew out the mentioned material thereby the material gets soaked with saliva.

\section{Segregation method:}

It is a device used to collect submandibular and sublingual saliva with the help of any masticatory stimuli.

\section{Cannulation:}

Tapered polyethylene tubes are used for the cannulation of Wharton's duct.

\section{PROCESSING OF SAMPLES}

Saliva samples must be processed over ice. Various types of equipment and supplies namely Laboratory vortex mixer, refrigerated centrifuge, cryotubes which are capable of accommodating $\left(-80^{\circ} \mathrm{C}\right)$ temperature, freezer $\left(-80^{\circ} \mathrm{C}\right)$ can be used..$^{25}$ Processing of samples at a lower temperature in ice facilitates the prevention of degradation of salivary proteins. The collected sample should be stored at an abutment temperature. ${ }^{26}$

\section{SALIVA ANALYSIS AND DIFFERENT TYPES OF TESTS AND PROCEDURES}

\section{Salivary proteomics and genomic target analy- sis for oral cancer biomarkers}

Previous researchers have examined proteins and nucleic acid in the saliva for cancer diagnosis by analyzing various 
candidate biomarkers. ${ }^{27}$ Following are the methods which are implicated for analysis it includes Luminex multianalyte profiling [XMAP] technology, Shotgun proteomics based on C4 reversed-phase liquid chromatography with quadruple time of flight mass spectrometry, Surface immobilized, optical protein sensor utilizing a confocal optics-based sensor, matrix-assisted laser desorption/ionization- mass spectroscopy (MAIDI-MS), reverse transcriptase quantitative polymerase chain reaction ( PT-qPCR), in-vitro translation, construction of salivary cDNA library, Human genome-wide U133A microleakage for profiling human salivary transcriptase. ${ }^{28}$ Comparison samples from oral cancer and control trials have demonstrated that oral fluid ${ }^{29}$ contains proteomic signatures that may serve as a biomarker for oral squamous cell carcinoma. mRNA biomarkers related to malignancies seven have been identified in OSCC saliva samples. ${ }^{30}$ They are transcripts of IL- 8, ILIB, DUSP, HA3, OAZ1, S100P, SAT.

\section{Comprehensive salivary analysis for oral can- cer diagnosis}

Saliva analysis of a previous study revealed an overall altered saliva composition in OSCC patients. ${ }^{31}$ In that, all OSCC lesions were located at the lateral aspect of the mobile tongue. The parameters included for the analysis includes sodium $(\mathrm{Na})$, potassium $(\mathrm{K})$, calcium $(\mathrm{Ca})$, inorganic phosphate $(\mathrm{P})$, magnesium $(\mathrm{Mg})$, total protein $(\mathrm{TP})$, albumin $(\mathrm{Alb})$, lactate dehydrogenase (LDH), amylase (Amy), total immunoglobulin $\mathrm{G}$ ( $\operatorname{IgG})$, secretory immunoglobulin A (Sec. IgA), epidermal growth factor (EGF), insulin growth factor I (IGF-I) and metalloproteinases MMP-2 and MMP-9. Indicating a compromised oral cancer environment suggested salivary analysis as an attractive, effective diagnostic tool for oral cancer. ${ }^{32}$

\section{Saliva DNA methylation in oral cancer}

Aberrant promoter hypermethylation patterns of cancer- related genes are detected in the saliva of head and neck cancer patients is reliable and potentially useful for detecting and monitoring disease recurrence. ${ }^{33}$ Investigation of Saliva DNA methylation can provide a lot of specific oncogenic genes that can be used as a possible biomarker for early diagnosis of oral cancer. Therefore, methylation analysis in the saliva is a very promising approach for early cancer detection in high-risk patients or for the post-treatment follow-up and rapid diagnosis of relapse. ${ }^{34}$ The methylation analysis might also reflect the tumor prognosis and complete the histology to define the diagnosis. Finally, DNA methylation is reversible with demethylating agents, a new avenue for cancer therapy in association with chemotherapy. ${ }^{35}$

\section{ADVANTAGES OF SALIVA BASED ORAL CANCER DIAGNOSIS}

Early diagnosis represents the target and as a role in the prognosis and further treatment. Saliva has multiple advantages over other body fluids that generated high interest among researchers. ${ }^{36}$ Saliva being a diagnostic fluid offers several advantages over serum for instance of its cost-effective approach, real-time diagnostic values, multiple samples can be collected easily from many people, less manipulation, noninvasive collection method, and with minimal risk of contamination. ${ }^{37}$ Unlike serum and tissue specimens, saliva has several advantages as a valuable diagnostic tool. ${ }^{38}$ One of the most important characteristics of salivary analysis is attributed to the noninvasive approach. Combined with the advantages of easy sample collection and storage makes it a valuable tool. ${ }^{39}$ New advances have demonstrated their viability and revealed an enormous number of salivary biomarkers that are associated with a few general and oral ailments. ${ }^{40}$

\section{DISADVANTAGES AND LIMITATIONS}

Lack of certain biomarkers, Portable detection systems are some of the limitations. Change in salivary flow may affect the concentration of protein present and make it less reliable. ${ }^{41}$ Composition and validation of saliva measurements are important for better diagnosis. Procedures done by unskilled professionals may lead to inaccuracy of the diagnosis. ${ }^{42}$ Salivary collection methods and biomarkers need to be standardized and validated. ${ }^{43}$ Also, new assays and devices need to be developed at a commercially feasible rate. ${ }^{44}$ However, much work needs to be done to incorporate saliva-based diagnostics into daily use. ${ }^{45}$ Saliva is a sensitive and specific salivary diagnostic tool, the establishment of defined guidelines will make salivary diagnostics methods a reality in the near future.

\section{DISCUSSION}

Saliva based oral cancer diagnosis has shown promising results and identified to be the most effective and reliable method. A previous study demonstrated the salivary transcriptome enzymes based diagnosis successfully; the microarray analysis showed around 1679 genes significantly. ${ }^{46}$ Various significant parameters have been implicated which include oxidative stress $^{47}$, immunological, biochemical factors. ${ }^{48}$ Further application of saliva in epithelial tumor markers has been discussed. ${ }^{49}$ The finding of a large panel of human RNA can be reliably detected in saliva gives rise to the potential of this novel clinical approach. Previous researchers also evaluated the potential biomarkers in human whole saliva and stated its effectiveness in early detection. ${ }^{50}$ Eventually, since saliva seems to be a valuable tool for diagnosis, much attention must be given to the procedures and techniques. ${ }^{51}$ Due to many favorable promising effects saliva will be used for the diagnosis of many diseases in future perspectives. 


\section{CONCLUSION}

This review compiles the utility of saliva-based diagnostic methods successfully for the detection of oral squamous cell carcinoma. Control mechanisms of salivary RNA turnover and the fate of these RNAs are also addressed. This is an ideal example of translational research in reverse, based on a highly relevant clinical observation that saliva contains proteomic and genomic biomarkers for oral cancer detection, and building a scientific foundation. This novel clinical approach could make use of a high therapeutic and effective tool for early detection of oral cancer. In the future, usage of saliva in this field will rely upon the validation and staging OSCC with specific biomarkers and multiplex measures that are specific, qualitative, rapid, cost-effective, and promising results in wider clinical application.

Author Contributions: Sarojini K, contributed to the data acquisition and drafting of manuscript. Dr. Brundha M.P. contributed to the design, editing, and critical revision of the manuscript. Dr. A.S. Smiline Girija contributed to the supervision and proofreading of the manuscript.

\section{ACKNOWLEDGEMENTS}

The authors are thankful to Saveetha Dental College for providing a platform to express our knowledge.

Conflict of Interest: The authors declare no conflict of interest.

\section{Source of Funding: Self}

Ethical Clearance: Not required

\section{REFERENCES}

1. Nagler R, Bahar G, Shpitzer T, Feinmesser R. Concomitant analysis of salivary tumor markers--a new diagnostic tool for oral cancer. Clin Cancer Res 2006 Jul 1;12(13):3979-84.

2. Shancy Merlin AR, Preejitha VB, Brundha MP. Estimation of salivary $\mathrm{pH}$ in hypertensive patients with and without periodontitis. Drug Inv Today 2020;14(4).

3. Markopoulos AK, Michailidou EZ, Tzimagiorgis G. Salivary markers for oral cancer detection. Open Dent J 2010 Aug $27 ; 4: 172-8$.

4. Brundha MP, Visha MG. A review on ankylosing spondylitis. Int J Clinicopathol Corr 2019;3: 44.

5. Arellano-Garcia ME, Hu S, Wang J, Henson B, Zhou H, Chia $\mathrm{D}$, et al. Multiplexed immunobead-based assay for detection of oral cancer protein biomarkers in saliva. Oral Dis 2008 Nov; 14(8):705-12.

6. Cheng YS, Rees T, Wright J. A review of research on salivary biomarkers for oral cancer detection. Clin Transl Med 2014;3:3.

7. Timothy CN, Samyuktha PS, Brundha MP. Dental pulp Stem Cells in Regenerative Medicine - A Literature Review. Res J Pharma Tech 2019;12: 4052.

8. Prashaanthi N, Brundha MP. A Comparative Study between Popplet Notes and Conventional Notes for Learning Pathology.
Res J Pharma Tech 2018;11: 175.

9. Kumar MDA, Ashok Kumar MD, Brundha MP. Awareness about nocturia-A questionnaire survey. Res J Pharma Tech 2016;9: 1707.

10. Mishra S, Saadat D, Kwon O, Lee Y, Choi W-S, Kim J-H, et al. Recent advances in salivary cancer diagnostics enabled by biosensors and bioelectronics. Biosen Bioelect 2016;81: 181-97.

11. Farah CS, Bhatia N, Lalla Y, Vu A, John K, Gupta V, et al. Advances in Early Detection and Diagnostic Adjuncts in Oral Cavity Cancer. Contemp Oral Oncol 2017;9: 355-421.

12. Ferdioz J, Brundha MP. Awareness of stye. Int J Pharma Sci Rev Res 2016 Jan 1;40(1):30-2.

13. Panta P, Wong DTW. Saliva-Based Point-of-Care in Oral Cancer Detection: Current Trend and Future Opportunities. Oral Cancer Detec 2019;23: 297-314.

14. Hannah R, Ramani P, Brundha MP, Herald. J. Sherlin, Ranjith G, Ramasubramanian A, et al. Liquid Paraffin as a Rehydrant for Air Dried Buccal Smear. Res J Pharma Tech 2019;12: 1197.

15. Chu HW, Chang KP, Hsu CW, Chang IYF, Liu HP, Chen YT, et al. Identification of Salivary Biomarkers for Oral Cancer Detection with Untargeted and Targeted Quantitative Proteomics Approaches. Mol Cell Proteo 2019;18: 1796-806.

16. Pickering V, Jordan RCK, Schmidt BL. Elevated salivary endothelin levels in oral cancer patients-A pilot study. Oral Oncol 2007;43: 37-41.

17. Sugimoto M, Wong DT, Hirayama A, Soga T, Tomita M. Capillary electrophoresis mass spectrometry-based saliva metabolomics identified oral, breast and pancreatic cancer-specific profiles. Metabolomics 2010 Mar;6(1):78-95.

18. Khurshid Z, Zohaib S, Najeeb S, Zafar M, Slowey P, Almas K. Human Saliva Collection Devices for Proteomics: An Update. Int J Mol Sci 2016;17: 846.

19. Wong DT. Towards a simple, saliva-based test for the detection of oral cancer. Exp Rev Mol Diagn 2006;6: 267-72.

20. Dhivyadharshini J, Brundha MP. Comparison of effects of interpretation of lab reports among the undergraduate dental students. Drug Invent Today 2020;14(3).

21. Golatowski C, Salazar MG, Dhople VM, Hammer E, Kocher T, Jehmlich N, et al. Comparative evaluation of saliva collection methods for proteome analysis. Clin Chim Acta 2013;419: 42-6.

22. Pavani NPM, Srinivas P, Kothia NR, Chandu VC. Recent Advances in the Early Diagnosis of Oral Cancer: A Systematic Review. Int J Med Rev 2018;4: 119-25.

23. Topkas E, Keith P, Dimeski G, Cooper-White J, Punyadeera C. Evaluation of saliva collection devices for the analysis of proteins. Clin Chim Acta 2012;413: 1066-70.

24. Henson BS, Wong DT. Collection, Storage, and Processing of Saliva Samples for Downstream Molecular Applications. Meth Mol Bio 2010: 21-30.

25. Bahar G, Feinmesser R, Shpitzer T, Popovtzer A, Nagler RM. Salivary analysis in oral cancer patients: DNA and protein oxidation, reactive nitrogen species, and antioxidant profile. Cancer 2007 Jan 1;109(1):54-9.

26. Hu S, Arellano M, Boontheung P, Wang J, Zhou H, Jiang J, et al. Salivary Proteomics for Oral Cancer Biomarker Discovery. Clin Cancer Res 2008;14: 6246-52.

27. Mager DL, Haffajee AD, Devlin PM, Norris CM, Posner MR, Goodson JM. Journal of Translational Medicine. 2005;3: 27.

28. Gouvea V, Glass RI, Woods P, Taniguchi K, Clark HF, Forrester $\mathrm{B}$, et al. Polymerase chain reaction amplification and typing of rotavirus nucleic acid from stool specimens. J Clin Microbiol. $1990 \mathrm{Feb} ; 28(2): 276-82$.

29. Harsha L, Brundha MP. Prevalence of dental developmental anomalies among men and women and its psychological effect in a given population. J Pharma Sci Res 2017;9(6):869-73. 
30. Swetha S, Brundha MP. Analysis of knowledge about the hospital warning symbols among the postgraduate dental students-A comparative study. Res J Pharma Tech 2017;10: 975.

31. Shpitzer T, Hamzany Y, Bahar G, Feinmesser R, Savulescu D, Borovoi I, et al. Salivary analysis of oral cancer biomarkers. $\mathrm{Br}$ J Cancer. 2009 Oct 6;101(7):1194-8.

32. Shreya S, Brundha MP. Alteration of Haemoglobin Value in Relation to Age, Sex and Dental Diseases-A Retrospective Correlation Study. Res J Pharma Tech 2017;10(5):1363-6.

33. Shpitzer T, Bahar G, Feinmesser R, Nagler RM. A comprehensive salivary analysis for oral cancer diagnosis. J Cancer Res Clin Oncol 2007;133: 613-7.

34. Nagler RM. Saliva as a tool for oral cancer diagnosis and prognosis. Oral Oncol 2009 Dec;45(12):1006-10.

35. Brundha MP, Pathmashri VP. Quantitative Changes of Red Blood cells in Cancer Patients under Palliative RadiotherapyA Retrospective Study. Res J Pharma Tech 2019;12(2):687-92.

36. Shah FD, Begum R, Vajaria BN, Patel KR, Patel JB, Shukla SN, et al. A Review on Salivary Genomics and Proteomics Biomarkers in Oral Cancer. Indian J Clin Biochem 2011;26:326-34.

37. Preethikaa S, Brundha MP. Awareness of diabetes mellitus among general population. Res J Pharma Tech 2018;11(5):1825-9.

38. Saivignesh S, Brundha MP. Myeloid sarcoma. Int J Clinicopathol Correl 2019 Jul 1;3(2):41.

39. Balaji S, Brundha MP, Path DNB. Awareness of About Breast Cancer among Dental Surgeons. Res J Pharm Biol Chem Sci 2016;8(8):797.

40. Brundha MP, Nallaswamy D. Hide and seek in pathology-A research on game-based histopathology learning. Int J Res Pharma Sci 2019;10(2):1410-4.

41. Radhika T, Jeddy N, Nithya S, Muthumeenakshi RM. Salivary biomarkers in oral squamous cell carcinoma - An insight. J Oral Biol Craniofac Res 2016;6: S51-4.
42. Brundha MP. A Comparative Study-The Role of Skin and Nerve Biopsy in Hansen's Disease. Res J Pharm Biol Chem Sci 2015;7(10):837.

43. Masooleh HS, Ghavami-Lahiji M, Ciancio A, Tayebi L. Microfluidic Technologies Using Oral Factors: Saliva-Based Studies. Appl Biomed Engi Dentist 2020:339-58.

44. Ravichandran H, Brundha MP. Awareness about personal protective equipments in hospital workers (sweepers and cleaners). Int J Pharma Sci Rev Res 2016;40(1):28-9.

45. Haritha PS, Brundha MP. Awareness of dengue fever among the parents of children coming to the dental outpatient department - A questionnaire study. Int J Clinicopathol Correl 2019 Jul 1;3(2):60.

46. Li Y, Elashoff D, Oh M, Sinha U, St John MAR, Zhou X, et al. Serum Circulating Human mRNA Profiling and Its Utility for Oral Cancer Detection. J Clin Oncol 2006;24: 1754-60.

47. Shenoy PB, Brundha MP. Awareness of polycystic ovarian disease among females of age group 18-30 years. J Pharma Sci Res 2016;8(8):813-6.

48. Kalaiselvi R, Brundha MP. Prevalence of hysterectomy in South Indian population. Res J Pharma Tech 2016;9(11):1941-4.

49. Panta P, Wong DTW. Salivary Biomarkers in Oral Cancer. Oral Cancer Detect 2019: 265-95.

50. Sowbaraniya SM, Preejitha VB, Brundha MP. Knowledge, awareness, and attitude on dental post-operative complications in diabetes among the general population. Drug Invent Today 2020;13(2).

51. Oh SY, Kang S-M, Kang SH, Lee H-J, Kwon T-G, Kim J-W, et al. Potential Salivary mRNA Biomarkers for Early Detection of Oral Cancer. J Clin Med 2020;9: 243. 